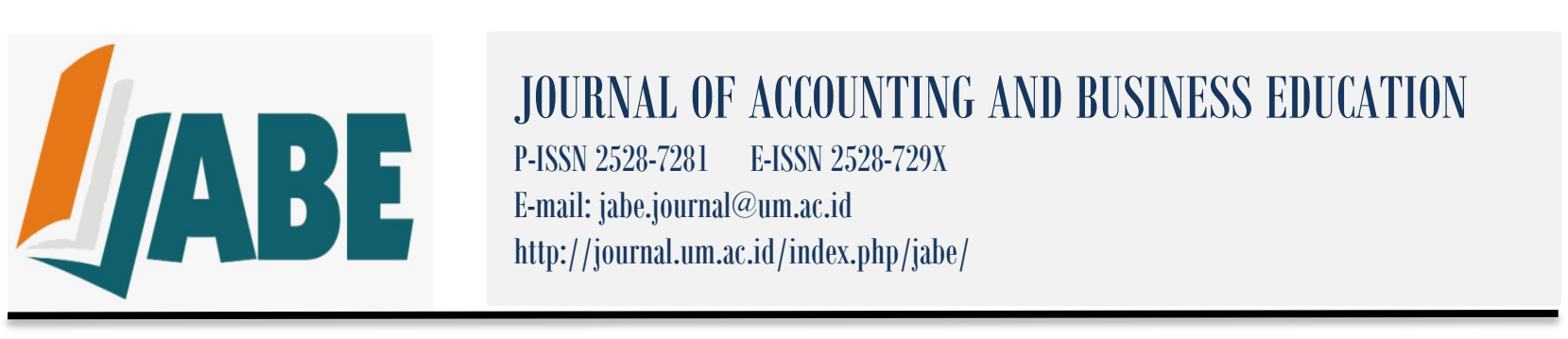

\title{
Performance Measurement Using Balanced Scorecard (BSC) (Study at Hospitals in Pasuruan)
}

\author{
Abd Rahman Taufik \\ Ali Djamhuri \\ Erwin Saraswati \\ Universitas Brawijaya \\ supermen.rohman@gmail.com
}

\begin{abstract}
Balanced scorecard (BSC) is a performance measurement method which is applied to private organizations to balance between financial and nonfinancial aspects. However, in this case, the financial measure of BSC application to non-profit public sector organizations is very different from private organizations. This study aims at measuring the performance of hospitals in Pasuruan based on four BSC perspectives (financial perspective, customer perspective, internal business process perspective, and learning and growth perspective). This study was conducted at the hospital using secondary data in the form of financial reports and non-financial reports. The object of this research was the hospitals in Pasuruan. The results showed that the performance of the three hospitals in Pasuruan in using BCS gauge is good. This reflects that the three hospitals in Pasuruan always strive to realize the achievement of vision, mission, and goals as one of the optimal public health services in Pasuruan and surrounding areas.
\end{abstract}

Keywords: Performance, Balanced Scorecard (BSC), Hospitals

\section{INTRODUCTION}

The hospital is no longer a non-profit public service institution but has become a business organization that is not free from competition and complete investment interests (Hseih et al., 2010). In the 21 st century, hospitals have become competing business organizations to obtain consumers by creating competitive advantage through optimal management of resources.

Optimal resource management must be able to provide efficient services for the needs and realize customer satisfaction, hence hospitals become part of health services (Putri, 2017 ). Therefore, hospitals must be able to improve performance, both short-term performance (shorttime) as well as long-term performance (long-time) (Herdiana, 2010). Surely this short and longterm performance will support the sustainability of the hospital business. Hospital success in increasing competitiveness, one of which is determined by the speed of response or sensitivity of the hospital in understanding customer needs (Asmid and Hollingsworth, 2013). 
One of the elements that need to be considered to improve hospital performance is by creating efficiency in operational activities. Efficiency measurement is a prerequisite for measuring the performance of a hospital, whether financially or non-financially. (Linddlbauer, et al., 2017).

There are 15 hospitals in Pasuruan (Radar Bromo.com, April 15, 2014) which consist of state-owned hospitals and private hospitals. The researchers determined Pasuruan because the hospital in Pasuruan was not maximized in achieving the hospital success indicators (indicators related to mortality, indicators related to outpatient care, and indicators related to hospital capacity) compared to Sidoarjo, Malang, Jember, and Banyuwangi (www.pdpersi.co.id).

The company's global competition will continue to increase, for that a performance measurement tool is needed that can not only measure several aspects but must be used to measure all aspects of the company. Therefore, complex performance measurements can provide more complete measurement results and are used as an overall performance evaluation (Wong and College, 2006).

Overcoming performance problems in companies requires improvement and performance improvement efforts that are assisted by using the balanced scorecard (BSC) measurement method. BSC is used as a tool to objectively evaluate performance by using an indicator of performance measurement in accordance with four perspectives, namely: financial perspective, customer perspective, internal process business perspective, and learning \& growth perspective (Kaplan and Norton, 2001).

The main priority in hospital development is to build an organizational performance system by conducting evaluations that produce an overall performance. The organizational performance will not provide optimal results if measured using only financial (traditional) measures, but also must be measured by non- financial measures. For that traditional performance measurement cannot reflect the overall performance of the organization (O'Donnel et al., 2011).

The BSC approach can provide information about employee performance and improve customer service satisfaction that is effective and efficient. Therefore, effective and efficient services are supported by quality and productive human resources to improve service efficiency and customer satisfaction with the aim of increasing hospital profits (Wang et al., 2008; Mitropoulos et al., 2013). 


\section{LITERATURE REVIEW}

Besides, that performance can also be interpreted as the level of achievement of the results of the completion of an activity related to good results. Performance, in general, is always associated with competition, concentration, efficiency, productivity, and the ability to be able to generate profits such as ROA (Anthun and Svarre, 2008).

Performance is also set as a standard based on the company's potential. For that performance is divided into two, namely: individual performance and organizational performance (Liung et al ., 2015). So it can be said that individual performance is the result of employee performance both in terms of quality and quantity based on predetermined work standards, while organizational performance is a combination of individual performance.

Performance can also provide information about financial statements such as the company's cash flow used to determine economic decisions and accountability for the use of resources called performance appraisal (Tuningrat et al ., 2012). Performance appraisal is an evaluation material for improving the performance of the future. Performance appraisal can also support the company's strategy to produce financial and non-financial performance (Boyd, 2000).

The measurement of the company's financial performance is not enough to be used as long-term information (Kotler, 2004). While the non-financial performance is more objective to be used as a measure of performance that can be measured according to the four perspectives contained in the balanced scorecard (BSC) (Rickard, 2007), including:

\section{Financial Perspective}

Measurement of financial performance is a consequence taken for the company's strategy to increase profits (Kaplan and Norton, 1996). Financial performance measurement will show whether the planning and implementation of the strategy will provide improvements with the aim of increasing company profits. These improvements are reflected in targets specifically related to measurable benefits, business growth, and shareholder value. Financial performance has three strategic aspects that are carried out, including revenue growth and a combination of income owned by business organizations, reduced costs and increased productivity, and optimal use of assets (Kadarova at., Al 2015). 


\section{Customer Perspective}

Currently, this part is considered important given the increasingly tight competition to retain customers. This section is also a source of corporate income, which is one component of the company's financial goals. In the past, companies often concentrated on internal capabilities, emphasizing product performance, innovation, and technology, but the obligation to understand what customers need.

Customer perspective identifies how the condition of our customers and target markets the company selected on a competitive basis. To determine the target market competitively is done by increasing customer satisfaction (Wasis, 2013). The customer perspective group is divided into two, namely: Core consumer measurement groups (market share, ability to reach new customers, customer retention ability, customer satisfaction level, and customer profitability) and measurement groups outside the core group (product/service attributes, customer relations, and image and reputation ).

\section{Process Business Internal Perspective}

Internal process business perspective is a series of organizational activities to create quality products or services in accordance with customer expectation. According to Valderamma, 2009 a quality internal business process perspective must always have innovation, operation, and after-sales service.

In the innovation process, business units examine the needs of customers who are developing or who are still hiding and then create products or services that will meet those needs. The operating process, the second major rarity in generic internal value chains, is the place where products and services are produced and delivered to customers. This process has historically been the focus of most corporate performance measurement systems.

\section{Learning \& Growth Perspective}

Learning growth perspective describes the organization's ability to make improvements and the change to take advantage of human resources (HR) (Kadarova et al., 2015). How important is a business organization to pay attention to HR by prospering and increasing employee knowledge. Prosperity and increasing employees can certainly improve service

efficiency and customer satisfaction in the hope of increasing company profits. The certain 
organization frequently pay attention to human resources to constantly organizations by increasing knowledge in order to create better results from three perspectives with the aim of increasing profit companies.

Learning \& growth perspective derives from three principles, namely people, system, and organizational procedure (Hsieh et al., 2010). Financial perspective, customer perspective, and internal business process perspective can reveal a large gap between the existing capabilities of people, systems, and procedures to what is needed to achieve a reliable performance. BSC emphasized the importance of human resource investment for the future that is based on three factors that must be considered (Kaplan and Norton, 1997), they are the ability to work, the ability of the information system, and motivation and empowerment.

\section{Hospital}

According to WHO (World Health Organization), the hospital is part of an organization's integration of social and health with the function of providing complete services (comprehensive), healing (curative) and preventing any spreading of disease (preventive) to the public. The hospital also provides health services that are promotive, at present and rehabilitating (Philips, 2012). The hospital also has function services as a medical service, medical and nonmedical support services, care, education, research, development, and general administration and finance (Ruslan, 2016).

The hospital consists of public hospitals and special hospitals. The public hospital is hospitals that provide health services for all types of diseases (Djojodibroto, 2008). While special hospitals are hospitals that provide the main service to a particular type of disease, based on the discipline of science or type of disease (Wicaksono, 2003). According to Minister of Health Republic of Indonesia No.340 / Menkes / Per / III / 2010 concerning on the classification of hospitals, the hospitals can be divided into several types such as based on ownership (Stateowned, private, foreign investment), based on type of service (heart, maternity referral hospital, eye hospital and others) based on class (class A, class B education and non-education, class C and class D). 


\section{Figure 1. Balance Scorecard Perspective}

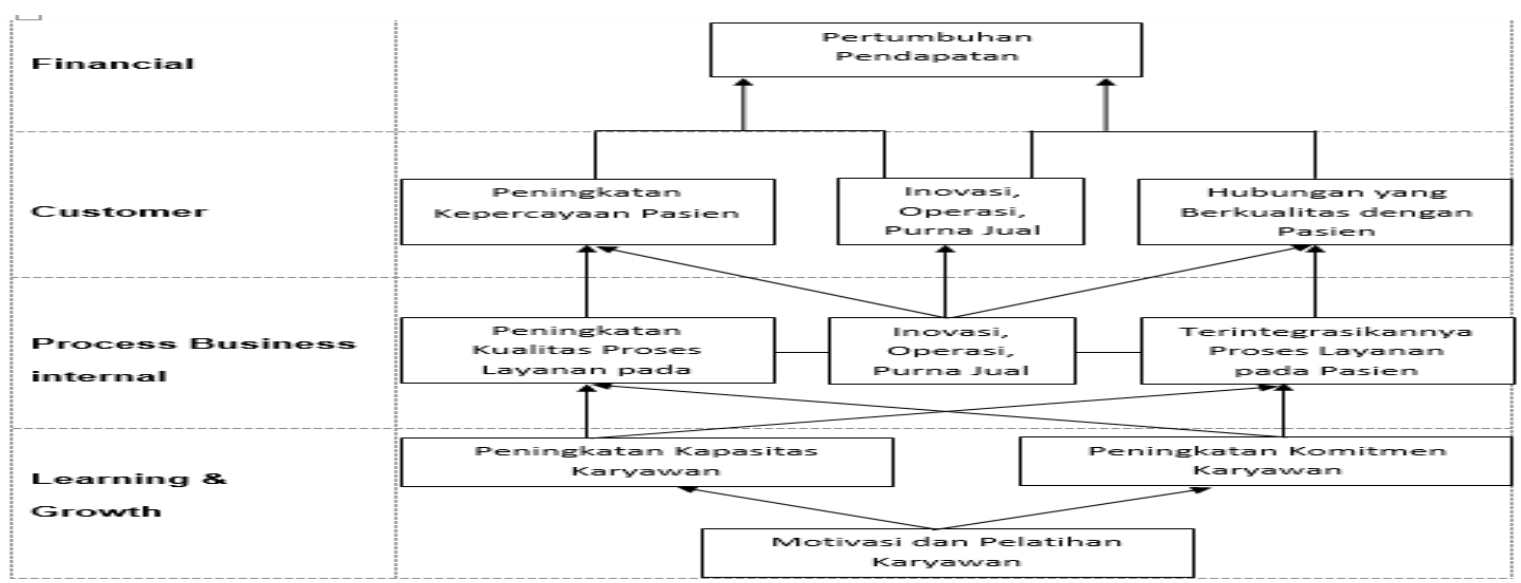

\section{An indicator of Hospital Success}

The indicator of hospital success is used to measure the extent to which the hospital can carry out operational activities effectively and efficiently. According to the Ministry of Health of the Republic of Indonesia in 2005 indicators of hospital success, including Indicators Relating to Death (GDR, NDR), indicators relating to the outpatient care, indicators relating to hospital capacity (BOR, BTO, TOI, ALOS).

By increasing the capacity and commitment of these employees, it can encourage employees to improve the quality of the service process in patients consisting of innovation, operation, and after-sales. Therefore, the service process can be integrated properly. Additionally, the quality of service is well integrated so that the speed of service will be achieved, later the trust and quality of the relationship with patients will increase and produce growth in hospital revenue and income.

\section{METHODS}

The determination of the object of this research is needed to assists in the implementation of the research to be more directed and successful. The research location was three hospitals in Pasuruan, East Java Province.

The data used in this case study were of two kinds, which include: primary data which was obtained directly from the relevant parties at hospitals for instance: financial reports and employee performance. The secondary data used to complete the basic data (primary data) obtained by the Health Office, Ministry of Health, Ministry of Health. 
Data collection techniques were systematic processes that were used to find and collect the necessary data, including:

a. Literature study, or to review the literature related to research conducted on the balanced scorecard to support research.

b. Observation, this is done by visiting and seeing the three hospitals institutions in Pasuruan as the object of research to match the data obtained from documentation and interviews.

c. Interview, which is a collection technique by interacting and communicating directly with parties related to research such as finance and personnel.

d. Documentation, namely data collection techniques done by studying various documents related to the issues within the research IT was used to obtain the primary and secondary data.

The data analysis was done in two methods, first qualitatively by using explanation hence a logical and relevant understanding will be obtained. Second, quantitatively, data analysis was made in numerical form using the BSC approach according to four perspectives, as follows:

1) Financial Perspective

$$
\text { Income Growth Rate }=\frac{\text { Income Growth }}{\text { Previous Year Income }} \times 100 \%
$$

2) Customer Perspective

a) Customer acquisition

b) Customer retention

$$
\text { Customer Acquisition }=\frac{\text { Current Customer Acquisition }}{\text { Previous Year Customer Acquisition }} x 100 \%
$$

$$
\text { Customer Retention }=\frac{\text { Preceding Customer Acquisition }}{\text { Previous Year Customer Acquisition }} \times 100 \%
$$

c) Gross death rate (GDR)

d) Net death rate (NDR)

$$
\mathrm{GDR}=\frac{\text { Mortality rate }}{\text { Inpatient }} x 100 \%
$$

$$
\mathrm{NDR}=\frac{\text { Mortality NUmber }- \text { Mortality Number } \leq 48}{\text { Inpatient }} \times 100 \%
$$

3) Process Business Internal.

a) Bed occupancy rate (BOR)

$$
\mathrm{BOR}=\frac{\text { Days of in }- \text { hospital }}{(\text { bed numbers } \mathrm{x} \text { days in one period })} \times 100 \%
$$

b) AThe averagelength of stay (ALOS)

$$
\text { ALOS }=\frac{\text { Days of in }- \text { hospital }}{\text { patient number }}
$$


c) Turn over internal (TOI)

$$
\text { TOI }=\frac{\text { (days number } \mathrm{x} \text { bed number) }- \text { in hospital number of days }}{\text { inpatient }}
$$

d) Bed turn over (BTO)

$$
\text { BTO }=\frac{\text { Number of Patients }}{\text { Number of beds }}
$$

\section{4) Learning \& Growth.}

The process of growth and learning comes from three factors, namely: human resources, systems, and organizational procedures. The benchmarks used in measuring employee growth and learning include employee satisfaction, information system capabilities, as well as motivation, empowerment, and alignment within the organization.

\section{RESULTS AND DISCUSSION}

\section{Financial Perspective}

To maximize the financial, hospitals must be able to optimize the costs with the aim of enhancing the growth of revenue. Enhancing revenue growth must consider several aspects, one of which is to optimize the cost (Reggiero, 2006). Based on observations showed that the three hospitals in Pasuruan were at the growth rate. All three hospitals have significant health services with a maximum growth rate. To maximize the growth rate, use a measuring instrument called with a revenue growth rate (growth rate in revenues). The income growth rate aims to determine the ability of the hospital every year by comparing the percentage of increase in income in the previous year.

Table 5.1 shows that the income generated by the three hospitals both in absolute and percentage increases every year. The increase in income is actually inseparable from the internal pain management business improvement of services and health service processes provided by hospitals. The increase in the income of the three hospitals came from health services in the form of outpatient visits, the number of inpatients occupancy, and the utilization of other supporting services such as diagnostic services, checkup, homecare, parking, and nutrition services. Therefore the hospital can be said to be labor intensive and capital intensive in carrying out business processes. 


\section{Customer Perspective}

To increase customer satisfaction, the hospital must pay attention to the facilities provided in order to obtain a customer. In enhancing competition to acquire and retain customers, companies must be able to determine the strategy of the right market (Wang, 2006). Before a customer performance benchmark is established, hospital management first determines the market segment that will be the target and needs of the customer. This market segment aims to determine the most appropriate and prospective market in running a hospital business process. Based on the observations, it shows that all three hospitals determined the market segment to all levels of the community and its surroundings. The measurement used by the three hospitals in customer performance are as follows:

\section{a) Core Group}

The core group aims to describe the results achieved by the hospital during operational activities. Benchmarks that can be used to measure core groups in the customer perspective are customer acquisition and customer retention.

The indicators of customer retention are used to determine the level of additional recent visitors in addition to the previous visitor with an added way of looking at the percentage of recent visitors in get a hospital for one year. Table 5.2 shows that the hospital's third acquisition customers increased for three years. The third increase in customer acquisition in hospitals is the result of hospital management efforts in improving the process of health services. However, customer acquisition cannot make it as an indicator of hospital success, because increasing customer acquisition is not only caused by the maximum service of the hospital, but also from other factors such as natural disasters.

Customer retention indicator is used to measure the extent to which the hospital is able to retain previous patients to choose health services provided by the hospital for one year. Table 5.2 shows that customer retention for three years was fluctuated inconsistently. The decreasing of customer retention in 2015 occurred because of internal hospital factors. But in 2016 there was an increase in in customer retention, although the increase was an insignificant the hospital management effort in providing comfort for the patient's health care services was done well. Therefore, hospital management must maintain and improve the health service process which consequently the patients can make a repeat visit. 


\section{b) Group Measurement Outside the Core Group}

To generate a level of satisfaction, trust, and loyalty of visitors, hospital management must pay attention to its image and reputation. The image and reputation of the hospital is an important factor that must be taken into account for the success and quality of services by the hospital. The high number of mortality can affect the image and reputation of the hospital. The indicator used to determine the size of the death rate is the indicator of gross death rate (GDR) and the indicator of the net death rate (NDR).

\section{Gross Death Rate (GDR)}

GDR indicators are used to assess the mortality rate of $\geq 48$ hours after being treated at the hospital for every 1,000 patients out. According to the Indonesian Ministry of Health (2005) the ideal GDR of $4.5 \%$. Table 5.3 shows that the GDR indicator of the three hospitals is ideal in the process of health care services provided to patients and the GDR values of the three hospitals are below the standard of the Ministry of Health RI. If the GDR value of a hospital is lower, the quality of hospital services is more effective and efficient. On the contrary, if the GDR value is higher, the quality of the service of the house is increasingly less effective. Therefore, it can be concluded that the GDR values of the three hospitals are below the standard of the Ministry of Health RI.

\section{Net Death Rate (NDR)}

NDR indicators are used to assess the mortality rate $\leq 48$ hours after being treated at the hospital for every 1,000 patients out. According to the Indonesian Ministry of Health (2005) the ideal NDR of 2.5\%. Table 5.3 shows that the third NDR indicator for hospitals in 2014 and 2015 almost close to the Ministry of Health standard of 2.5\%, and in 2016 the three hospitals can be said to be ideal. If the NDR value of a hospital is higher, the quality of service can be considered less effective. Conversely, if the hospital NDR is low, the quality of service can be considered effective and efficient. Therefore, it can be concluded that in 2014 and 2015 the three hospitals were not ideal and in 2016 the three hospitals were ideal. 


\section{Process Business Internal Perspective}

The success in creating satisfaction and hospital customer trust is obtained by developing internal business processes which must include:

\section{a) Innovation}

Innovation which is carried out and developed by the three hospitals are: RS 1 continues the construction of hospital building equipped with health service facilities and infrastructure as well as renovation of other health service rooms in order to improve hospital services. RS 2 continues to renovating the place of registration for outpatients, inpatients and pharmacy buildings. RS 3 carries out inpatient construction and procurement of ambulances.

\section{b) Operation}

\section{Bed occupancy rate (BOR)}

The BOR indicator shows the level of use of a bed occupied by a patient for a certain period of time. According to the Ministry of Health RI (2005). The ideal BOR is between 60$85 \%$. Table 5.4 shows that the hospital BOR levels for three years are ideal and the income growth increases. Overall the hospital's bed utilization rate in three hospitals are above 50\%. This shows that the level of utilization of the third bed of the hospital can still be increased for maximum use.

\section{Bed Turn Over (BTO)}

The BTO indicator shows the average rate of use of one bed in a given period of time. BTO indicators have the benefit of assessing the efficiency of hospital bed usage. According to the Ministry of Health of Indonesia (2005), the ideal BTO is 40-50 times. The following results of the BTO of the three hospitals can be seen in table 5.6. Table 5.6 shows that the BTO level of the three hospitals is ideal and the hospital income growth increases. For this reason, the use of one bed in the three hospitals are used efficiently. This figure has met the standards of the Ministry of Health of Indonesia (2005).

\section{Average Length Of Stay (ALOS)}

The ALOS indicator shows the length of time a patient stays in a hospital in order to perform health care. This ALOS figure is an indication of whether the hospital can provide fast, precise and accurate health services. So that patients do not need a long time to stay in the hospital. According to the Ministry of Health of Indonesia (2005), the ideal number of ALOS is 
6 to 9 days. Table 5.6 shows that the ALOS operating process for the three hospitals is ideal in providing good service in time, quality and cost.

\section{Turn Over Internal (TOI)}

The TOI indicator shows the number of days the bed is occupied by the patient since the patient is left and occupied by the next patient. The TOI number is used as an indicator that measures hospital efficiency, especially for hospitalization. According to the Ministry of Health of Indonesia ( 2005), the ideal number of TOI is 3 days. Table 5.7 shows that the quality of services provided by the three hospitals to sterilize beds is ideal and effective, hence the possibility of having a bed that has been sterile from previous diseases and can optimize the use of beds owned by hospitals.

\section{c) After Sales Service}

Hospital after-sales service is an activity to create additional value to the customer for the health services that have been provided. The after-sales service that has been carried out by three hospitals so far is facilitating the process of Healthcare and Social Security Agency (BPJS) and the procedure in recording complaints and the solutions do not take a lengthy process.

\section{Perspectives Learning \& Growth}

The first goal in the perspective learning \& growth is to increase employee satisfaction and motivation. The high level of satisfaction and motivation of employees will help in to realize the goals of the hospital. The second goal is an increase in the achievement of job training. Job training can help hospitals to improve the quality of their human resources.

The outcome measure of increasing the achievement of job training is the level of employee participation in education and training activities. A high level of employee participation can improve the ability of employees owned by hospitals. Therefore, with the training and education carried out on a scale basis, it can improve optimal human resources. HR measurement tools were using a Likert scale to measure employee perceptions, attitudes or opinions regarding the phenomena that occur in the hospital. This assessment used a Likert scale which has a score of 1 to 5 (Tuningrat et al., 2012) which is presented in Table 5.8.

The researchers measured the performance of the three hospitals in this perspective using data on an employee in the outpatient and inpatient installations in each hospital. The following 
are the benchmarks for employee performance that are used in the perspective learning \& growth for all three hospitals, including:

\section{Employee Satisfaction}

HR is the most important organizational asset in operational activities every day in the hospital. The human resources in the hospital must have the potential in the form of desires, abilities, knowledge, and skills to achieve organizational goals. Table 5.9 shows that employee satisfaction with work, colleagues, and promotion opportunities of these three hospitals are satisfactory. This is in accordance with the expectations of the hospital that has been done by employees. While employee satisfaction for rewards and supervisor supervision needs to be considered and increased again hence the employees can feel satisfied with the work so far.

\section{Information System Capabilities}

The hospital management information system (SIMRS) is a computer system that processes and integrates the entire flow of business processes in hospitals. The flow of the health service business process can form a network to coordinate, report, and administrative procedures in obtaining information quickly, accurately and accurately. SIMRS as a very important means of supporting information can even be said to be absolute to support the process of managing hospital operational data. The ideal SIMRS can certainly reduce the workload in each health service unit.

Table 5.10 shows that the ability to use SIMRS on user satisfaction and top management support in developing SIMRS is satisfied, this is in accordance with the needs of the hospital. While the training and formalization of SIMRS development are quite satisfied. Therefore, it is necessary to improve and socialize with the information and technology (IT) so that users and developer of SIMRS can work together to obtain the results expected by the hospital.

\section{Motivation, Alignment, and Harmony}

Motivation is an attempt to stimulate or encourage hospital employees to work optimally in achieving their stated goals. Table 5.11 shows that work that is in accordance with the ability of employees and hospital policies of employees is satisfied, this is in line with the expectations desired by the hospital. While the awarding and training of hospital employees is quite satisfied, 
it is necessary to pay attention to the hospital management, especially the boss. Therefore, the role of superiors in motivation, empowerment, and employee safety are needed to encourage each other in achieving the goals expected by the hospital.

The results of research on the measurement of the performance of the three hospitals using the BSC approach according to the four perspectives described above show good results. Business position the three hospitals are currently in the stage of growth, so all three hospitals need support from internal factors and external factors to develop hospital health services. The measurement of perspective financial shows that the income growth rate is quite good, this is certainly inseparable from the customer perspective. While the trigger factors of satisfaction and trust and loyalty of customer are costs and services so that improvements in service quality and cost stability need to be carried out by hospital management to strengthen image and reputation.

Service improvements can be carried out by improving internal business the hospital's process which consists of the process of innovation, operation, and after-sales service. The perspective internal business process hospitals is satisfactory, therefore employee productivity and commitment need to be improved in order to support the three previous performance. Increased productivity and employee commitment need to be done by involving all employees in the decision making the process for the improvement of the hospital and encouraging employees to do creativity and work initiatives.

\section{CONCLUSION}

If the four BSC perspectives are applied to all three hospitals, the results that can be seen from the measurement of performance in the perspective are financially measured using the level of hospital income growth. The level of hospital income growth shows maximum results, this can be seen from the level of income every year which there is a frequent increase. Customer perspective measurement was measured using indicators of customer acquisition and customer retention. This indicator was used to measure the number of new patient and measure how great the hospital can maintain the previous patient. While the level of quality of hospital services was measured by using GDR and NDR indicators. The results of each indicator show satisfactory results in accordance with the Ministry of Health standards (2005).

The perspectives of internal process business of the three hospitals are quite good, this can be seen from innovation, operations, and after-sales service. The innovations carried out and 
developed by the three hospitals are first are: RS 1 continues the construction of hospital building equipped with health service facilities and infrastructure as well as renovation of other health service rooms in order to improve hospital services. RS 2 continues to renovating the place of registration for outpatients, inpatients and pharmacy buildings. RS 3 carries out inpatient construction and procurement of ambulances.

While the operating process can be seen from the indicators of BOR, BTO, ALOS, and TOI are ideal in accordance with the standards of the Ministry of Health (2005). For after-sales services performed by the three hospitals, it is easy to process Healthcare and Social Security Agency (BPJS) and the procedure in recording complaints and the solutions do not take a lengthy process. The third performance of the hospital in terms of perspective learning $\&$ growth can be considered good, this can be seen from the data on hospital employee which includes the ability of employees, information system capabilities, as well as motivation, dissemination, and alignment which on average which show good results.

\section{REFERENCES}

Asmild, M., \& Hollingsworth, B. (2013). the Scale of Hospital Production in Different Settings: One Size Does Not fit all. Journal of Productivity Analysis, 40, 197-206.

Anthun, K. S., \& Svarre, A. C. K. (2017). Productivity Growth, Case Mix and Optimal Saze of Hospital. A 16-year Study of The Norwegian Hospital Sector. Health Policy. 121 (2017) 418-425.

Barros, C.P, \& Dieke, P.U.C., (2008). Techical Efficiency of African Hotels. Internasional of Hospitality Management 27 (3), 4380447

Boyd, M (2000). Pendekatan Strategis Dengan Orientasi Global. Tesis. Universitas Indonesia.

Carrillo, M \& Jesus, M. (2015). A Multiobjective DEA Approach to Ranking Alternatives. Expert Systems With Applications 50 (2015) 130-139.

Depkes RI. (2009). Undang-undang Republik Indonesia Nomor. 44 Tahun 2009 Tentang Rumah Sakit. Jakarta: Depkes RI.

Djojodibroto, D. R. (2008). Pengelolan Rumah Sakit Dengan Disiplin Ilmu dan Etika Profesi. Tesis. Universitas Airlangga. Surabaya.

Eilat H., Golany, B., \& Shtub, A. (2008). R\&D Project Evaluation: An Intergrade DEA And Balanced Scorecard Approach. Omega, 36, 895-912.

Hasan, I (2012). Pengaruh Pendendalian Intern Terhadap Kinerja Layanan Dengan Good Govermence dan Budaya (Studi pada Rumah Sakit di Sulawesi Tengah). Tesis. Universitas Brawijaya. 
Herdiana, D (2010). Analisis Pengukuran Kinerja Dengan Rerangka Model Integrasi Balanced Scorecard dan Six Sigma RSU Dr. Saiful Anwar. Tesis. Universitas Brawijaya. Malang.

Hsieh L. F., King. L. F \& Li L. F (2010). A Performance Evalution Model for International Tourist Hotels in Taiwan-An Application of the Ralitonal Network DEA. Internatioanl Journal of Hospital Manahement. 29 (2010) 14-24.

Kadarova, J. J. R. T. (2013). Proposal of Performance Assessment by Integration of Two Management Tools. DOI: 10.12776/QIP.V1771.143. ISSN 13355-1745.

Kadarova, J. J. R. T., Michaela, K \& Gabriel K. (2015). The Proposal of an Innovative Integrated BSC-DEA Model. Procedia Economics and Finance 23 (2015) 1503-1508.

Kaplan, R. S., \& Norton, D. P. (1992). The Balance Scorecard - Measures That Drive Performance. Harvard Business Review, 70(1), 71-79.

Kaplan, R. S., \& Norton, D. P. (1996). Using The Balance Scorecard As A Strategic Management System. Harvard Business Review, 74(1), 75-85.

Kaplan, R. S., \& D. P. Norton. (2000). Alignment: Using The Balanced Scorecard to Create Corporate Synergies. Harvard Business School Press, Boston.

Kaplan, R. S., \& David P. N. (2001). Transforming the Balanced Scorecard from Performance Measurement to Strategic Management Part II. Accounting Horizons. Vol. 15 No. 2 June 2001 pp.147-160.

Kaplan, R. S., \& Norton, D. P. (2004). Measuring The Strategic Readiness Of Intangible Assets. Harvard Business Review, 82(2), 52-63.

Kotler, P. (2008). Reconceptualizing Marketing: An Interview With Philip Kotler. European Management Journal. Volume 12. Issue 4, December 2008.

Lindlbauer I., Jonas S., \& Vera W (2016). Change in Technical Effeicienscy After Quality Managemen Certification: A DEA Approach Using Difference-in- Difference Estimation With Genetic Matching in the Hospital Industru. European Journal of Operation Reseacrh. 250(2016) 1026-1036.

Liung H., Tantri Y., \& Rahmat S. H. (2015). Pengaruh Kualitas Layanan Terhadap Kepuasan Dalam Meningkatkan Loyalitas Di Moderasi Harga dan Biaya. Jurnal Ekonomi Volume 8 Nomor 2, Mei.

Mitropoulos P., Michael A. T., \& Ionnis M. (2015). Combining Stochastic DEA With Bayesian Analysis To Obtain Statistical Properties Of The Effiency Scores: An Application To Greek Public Hospital. European Jornal of Operational Researc 243 (2015) 302-311.

O’Donnell, C., Fallah F S., \& Triantis, K. (2011). Comparing Firm Performance Using Transitive Productivity Index Numbers In A Meta-Frontier Framework. CEPA Working Papers Series WP082011. Australia: School of Economics, University of Queensland.

Philips, P.A. (2012). Performance Measurment Systems And Hotels: A New Conceptual Fremwork. International Journal of Hospitality Management 18 (2), 171-182. 
Rickards, R. C. (2007). BSC And Benchmark Development For An E-Commerce SME. Benchmarking, 14, 222-250.

Reggiero, J. (2006). Measurement Error, Education Production And Data Envelopment Analysis. Economics of Educations Riview 25 (2005) 327-333.

Ruslan, E. (2016). Pengukuran Kinerja dengan Menerapkan Konsep Balanced Scorecard dan Six Sigma (Studi Kasus pada Rumah Sakit di Sidoarjo). Tesis. Universitas Airlangga.

Putri, R. (2017). Hubungan Antara Tingkat Pendidikan Dan tingkat Pengetahuan Dengan Perilaku Hidup Sehat Kualitas Lingkungan Rumah (Studi Masyarakat Kabupaten Pringsewu, Keseluruhan Pringsewu Barat). Tesis. Universitas Lampung.

Sekhon, J. S. (2011). A Matching Method for Improving Covariate Balanced in CostEffectiveness Analyses. Health Economics, 2 (6), 695-172.

Sgala, M., Jones, P., \& Lockwood, A., A. D. (2005). Productivity in hotels: a Stapwise data envelopment analysis of Hotels Room Division Processes. The Service Industries Journal 25 (1), 61-81.

Sucipto, S. K. (2009). Pengukuran Performasi dan Efisiensi dengan Menggunakan Balance Scorecard dan Data Envelopment Analysis Berdasarkan Kriteria Balance Scorecard. Tesis, Jurusan Teknik Industri, Institut Teknologi Sepuluh Nopember, Surabaya.

Thanassoulis, E. \& Dunstan, P. (2004). Guiding Schools to Improved Performance Using Data Envelopment Analysis; An Illustration With Data from a Local Education Authority. The Journal of the Operational Research Society 45 (11), 1247-1262.

Tuningrat, Ida A. M, I Ketut S., \& I Gusti A. S. L. (2012). Analisis Tingkat Kepuasan Karyawan Terhadap Kompensasi Yang Diberikan Perusahaan (studi Kasus di Perusahaan Kopi Banyuatis). Piramida Vol. VIII No. 2:114-120. Desember 2012.

Valderamma, (2009). Relating the Perpectives of the Balanced Scorecard R\&D by Means of DEA”. European Journal of Operational Research 196: 1177-1189.

Valderrama, Terasa G., Eva M., \& Daniel R. B. (2009). Relating The Perspectives Of The Balanced Scorecard For R\&D By Means Of DEA. European Journal of Operations Research 196 (2009) 1177-1189.

Wang, Y. G., Chyan L. J., \& Kuang W. C. (2013). Evaluating Firm Performance with Balanced Scorecard and Data Envelopment Analysis. Issue, volume 10, Januari 2013.

Wasis. (2013). Rancangan Balanced Scorecard Sebagai Instrument Pengukuran Kinerja Di Rumah Sakit Citra Medika Sidoarjo. Tesis. Universitas Airlangga.

Wang, H. C. (2006). Corporate Performance Efficiency Investigated by Data Envelopment Analysis and Balanced Scorecard. The Journal of American Academy of business, Cambridge 9.

Wicaksono, M.S. (2003). Analisis Kualitas Pelayanan Dalam Mempengaruhi Kepuasan Pasien Rumah Sakit BeRS 3lin Di Kota Malang. Tesis. Universitas Brawijaya. Malang. 
Wong, J. C \& College H. W. (2006). Coorporate Performance Efficiency Investigated by Data Envelopment Analysis and Balanced Scorecard. The Journal of American Academy of Business. Vol. 9. Num.2.

\section{APPENDIX}

Table 5.1

Growth Rate In Revenues

\begin{tabular}{lcccc}
\hline & Hospitals & \multicolumn{3}{c}{ Year } \\
\cline { 2 - 4 } & & $\mathbf{2 0 1 4}$ & $\mathbf{2 0 1 5}$ & $\mathbf{2 0 1 6}$ \\
RS 1 & $16,83 \%$ & $17,51 \%$ & $22,89 \%$ \\
RS 2 & $13,04 \%$ & $15,83 \%$ & $17,12 \%$ \\
RS 3 & $11,94 \%$ & $14,40 \%$ & $15,23 \%$ \\
\hline
\end{tabular}

Table 5.2

Core Group

\begin{tabular}{lrll}
\hline \multicolumn{1}{c}{ Hospitals } & \multicolumn{3}{c}{ Year } \\
\cline { 2 - 4 } Customer Acquisition & $\mathbf{2 0 1 4}$ & $\mathbf{2 0 1 5}$ & $\mathbf{2 0 1 6}$ \\
RS 1 & & & \\
RS 2 & $20,36 \%$ & $23,83 \%$ & $28,22 \%$ \\
RS 3 & $13,26 \%$ & $14,01 \%$ & $16,05 \%$ \\
Customer Retention & $12,42 \%$ & $12,51 \%$ & $13,19 \%$ \\
RS 1 & & & \\
RS 2 & $94,55 \%$ & $85,92 \%$ & $89,42 \%$ \\
RS 3 & $109,02 \%$ & $88,42 \%$ & $89,70 \%$ \\
\hline
\end{tabular}

Table 5.3

Kelompok Pengukuran Diluar Kelompok Utama

\begin{tabular}{llll}
\hline & Hospitals & \multicolumn{3}{c}{ Year } \\
\cline { 2 - 4 } GDR & $\mathbf{2 0 1 4}$ & $\mathbf{2 0 1 5}$ & $\mathbf{2 0 1 6}$ \\
RS 1 & & & \\
RS 2 & $2,74 \%$ & $2,66 \%$ & $2,53 \%$ \\
RS 3 & $2,79 \%$ & $2,69 \%$ & $2,56 \%$ \\
NDR & $2,78 \%$ & $2,71 \%$ & $2,31 \%$ \\
RS 1 & & & \\
RS 2 & $2,49 \%$ & $2,45 \%$ & $2,37 \%$ \\
RS 3 & $2,56 \%$ & $2,46 \%$ & $2,31 \%$ \\
\hline
\end{tabular}


Table 5.4

Bed Occupancy Rate

\begin{tabular}{lccc}
\hline & Hospitals & \multicolumn{3}{c}{ Year } \\
\cline { 2 - 4 } & $\mathbf{2 0 1 4}$ & $\mathbf{2 0 1 5}$ & $\mathbf{2 0 1 6}$ \\
RS 1 & $68,51 \%$ & $83,43 \%$ & $93,29 \%$ \\
RS 2 & $64,48 \%$ & $64,88 \%$ & $65,46 \%$ \\
RS 3 & $67,45 \%$ & $68,49 \%$ & $68,79 \%$ \\
\hline
\end{tabular}

Table 5.5

Bed Turn Over

\begin{tabular}{|c|c|c|c|}
\hline \multirow[t]{2}{*}{ Hospital } & \multicolumn{3}{|c|}{ Year } \\
\hline & 2014 & 2015 & 2016 \\
\hline RS 1 & 42,67kali & 43,67 kali & 44,07 kali \\
\hline RS 2 & 48,99kali & 49,72 kali & 50,51 kali \\
\hline RS 3 & 51,49 kali & 51,73 kali & 52,46 kali \\
\hline
\end{tabular}

Table 5.6

Average Length Of Stay

\begin{tabular}{lrrr} 
& Hospitals & \multicolumn{3}{c}{ Year } \\
\cline { 2 - 4 } RS 1 & $\mathbf{2 0 1 4}$ & $\mathbf{2 0 1 5}$ & $\mathbf{2 0 1 6}$ \\
RS 2 & 6 hari & 7 hari & 8 hari \\
RS 3 & 5 hari & 5 hari & 5 hari \\
\hline
\end{tabular}

Table 5.7

Turn Over Internal

\begin{tabular}{lcrr}
\hline & Hospitals & \multicolumn{3}{c}{ Year } \\
\cline { 2 - 4 } & $\mathbf{2 0 1 4}$ & $\mathbf{2 0 1 5}$ & $\mathbf{2 0 1 6}$ \\
RS 1 & 3 hari & 1 hari & 1 hari \\
RS 2 & 3 hari & 3 hari & 3 hari \\
RS 3 & 2 hari & 2 hari & 2 hari \\
\hline
\end{tabular}

Table 5.8

Likert Scale

\begin{tabular}{l|c}
\hline \multicolumn{1}{c|}{ Remarks } & Score \\
\hline Dissatisfied & 1 \\
Quiet Dissatisfied & 2 \\
Quite Satisfied & 3 \\
Satisfied & 4 \\
Very Satisfied & 5 \\
\hline
\end{tabular}


Table 5.9

Employee Satisfaction

\begin{tabular}{lccc}
\hline \multicolumn{1}{c}{ Remarks } & \multicolumn{3}{c}{ Score } \\
\cline { 2 - 4 } & RS 1 & RS 2 & RS 3 \\
1. Satisfaction of the work & 4 & 4 & 4 \\
2. Satisfaction of the payment & 3 & 3 & 3 \\
3. Satisfaction of the supervision & 3 & 3 & 3 \\
4. Satisfaction of the co-workers & 4 & 4 & 4 \\
5. Promotion opportunity & 4 & 4 & 4 \\
\hline
\end{tabular}

Table 5.10

The Capability of SIMRS

\begin{tabular}{lccc}
\hline \multicolumn{1}{c}{ Remarks } & \multicolumn{3}{c}{ Score } \\
\cline { 2 - 4 } & RS 1 & RS 2 & RS 3 \\
6. Satisfaction of SIMRS users & 4 & 4 & 4 \\
7. Trainin of SIMRS using & 3 & 3 & 3 \\
8. Top-down management support for SIMRS & 4 & 4 & 4 \\
$\quad$ development & & & \\
9. SIMRS Development formalization & 3 & 3 & 3 \\
\hline
\end{tabular}

Table 5.11

Motivation, Conformity, and Suitability

Remarks

10. Rewards for employee

11. Training for employee

\begin{tabular}{ccc}
\multicolumn{3}{c}{ Sscore } \\
RS 1 & RS 2 & RS 3 \\
3 & 3 & 3 \\
3 & 3 & 3 \\
4 & 4 & 4
\end{tabular}

12. The job which is in accordance with the capability of employee

13. Flexible policy of hospital

4 4 